\title{
Chimeric antigen receptors: unleashing a new age of anti-cancer therapy
}

Yan Leyfman * (1)

\begin{abstract}
Background: Chimeric antigen receptors (CARs) represent a novel facet of modern day synthetic biology that exemplifies personalized medicine at work through their ability to harness and redirect a patient's immune system to fight cancer.

Body: By combining the target-specificity of antibodies to the effector capabilities of T cells, CARs have yielded high remission rates for many late staged and relapsed/refractory $(r / r)$ hematological malignancies, including acute lymphoblastic leukemias (ALL) and Non-Hodgkin's lymphomas. Despite toxicities of cytokine release syndrome and neurotoxicity, recent studies have uncovered their underlying mechanisms and devised effective therapies to manage and possibly prevent them. In 2017, CART cell therapy became a reality for the general public despite the high costs, when Novartis's Kymriah, became the first product to receive FDA approval for pediatric r/r B cell ALL with Gilead's Yescarta following several months later. Although effective in hematological malignancies, CAR response has been limited in solid tumors largely attributed to the heterogeneous and immunosuppressive tumor microenvironment along tumor defense mechanisms, such as antigenic escape.

Conclusion: Despite the current challenges of CART therapy, this technology is still in its infancy and its promise will continue to grow as scientists continue to develop novel approaches to enhance its efficacy. As its prevalence continues to increase, institutions and pharmaceuticals worldwide are investing in this technology in hopes of driving therapeutic innovation, while providing greater access to their respective populations through clinical trials.
\end{abstract}

Keywords: Chimeric antigen receptor, Leukemia, Hematological malignancy, T cell, Immunotherapy, Solid tumor, CAR resistance

\section{Introduction and history}

Since 1935, cancer has remained the second leading cause of death in the United States with a steadily increasing number of new cases yearly [1]. Although standard anti-cancer drugs, which are predominantly nonselective cellular poisons that indiscriminately target the most metabolically active cells, are used, cancer mortality rates remained constant from 1950 to 2005 in late stage disease according to the American Cancer Society [2]. Medication prices, however, have continued to skyrocket with increases by as much as 1400\% since 1976 for

*Correspondence: yleyfman@pennstatehealth.psu.edu; yan.leyfman@gmail.com

Penn State College of Medicine, 61A University Manor East, Hershey, PA, USA certain cancer subtypes [1]. Scientists believed that they could rectify this by harnessing the power of a patient's immune system to fight this disease; this in turn led to the development of CAR T cell therapy-an example of personalized medicine at work, whereby each patient's immune cells can act as a living drug to enhance the immune response to combat disease.

Chimeric antigen receptor $\mathrm{T}$ cells, a unique facet of modern-day synthetic biology, combine the targeted specificity of antigens with the downstream intracellular signaling potential of a $T$ cell receptor to enhance $T$ cell potency and function [3]. Interaction with antigen leads to CAR activation and the turning on of downstream $T$ cell signaling pathways to yield cytotoxic killing through granzymes and perforins and enhanced immune response through cytokine release [4]. First-generation 
CARs, which consisted of only an HLA-independent extracellular domain and an intracellular $\mathrm{T}$ cell activating domain comprised of the zeta chain of the CD3 complex, exhibited limited efficacy due to their inability to sustain $\mathrm{T}$ cell signaling responses [5]. This was rectified with the creation of second-generation CARs, which contained a co-stimulatory receptor to enhance $\mathrm{T}$ cell function, expansion, and efficacy [6]. Third generation CARs have multiple co-stimulatory domains to further enhance $T$ cell function and efficacy [3]. Achieving successful results at the bench, second-generation CARs entered clinical trials in 2009. In this single treatment, a patient's $T$ cells were harvested, activated ex vivo with antibody-coated beads, transduced with a lentiviral vector bearing the CAR, expanded, purified, cryopreserved, assessed for quality, and then reinfused into the patient after conditional chemotherapy (Fig. 1) [7]. The quality control assessment is based on the United States Food and Drug Administration (USFDA) protocol guidelines that assesses safety, sterility and potency. Safety testing is performed to show that this product can be given to humans without harm. Sterility testing ensures that the product is without microbiological contaminants and free from impurities, including remnants of assays, vectors, and growth media. Vector product potency is performed to ensure that the identity and function of the
CAR product are what it should be [8]. Direct clinical application of this protocol was first performed in 2010 by physicians at the National Cancer Institute who were the first to demonstrate the clinical efficacy of CAR T cell therapy, when they successfully induced regression of advanced lymphoma in one patient [9]. In 2011, Memorial Sloan Kettering Cancer Center (MSKCC) became the first institution to demonstrate complete remission of relapsed/refractory B-cell acute lymphoblastic leukemia ( $r / r$ B-ALL) in 8 patients in their Phase I clinical trial [10]. When expanded to 38 patients, the overall complete remission rate in this trial was $87 \%$ with a median time to complete remission lasting only 23 days and a complete bone marrow recovery within 2 months [11]. In 2012, similar results for $\mathrm{r} / \mathrm{r}$ B-ALL were demonstrated by the Children's Hospital of the University of Pennsylvania when 7-year old Emily Whitehead successfully achieved complete remission [12].

\section{Side effects and solutions}

Despite these clinical successes, CAR T cells have been shown to cause several potent side effects. Cytokine release syndrome (CRS) occurs when CARs overstimulate the immune response through cytokine release leading to respiratory distress, hypotension and fever [10]. Physicians are able to adequately control this with

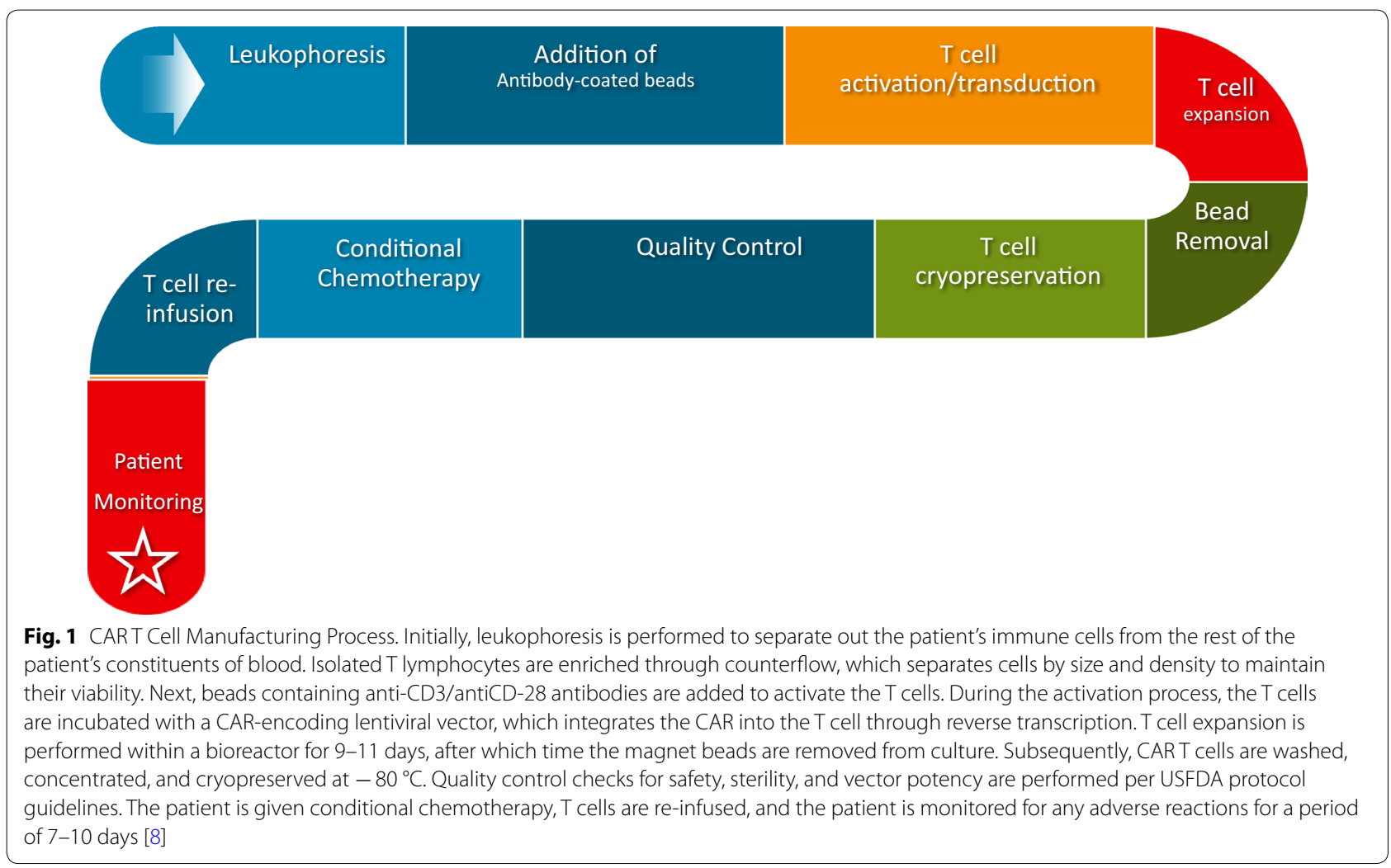


Tocilizumab (a humanized monoclonal antibody against the IL-6 receptor) and high dose steroids if refractory [11]. However earlier this year, scientists discovered that CRS is actually caused by macrophages hypersecreting IL-1 and can be effectively managed by IL-1 receptor inhibitors, such as Anakinra [13].

Another potent side effect of this therapy is neurotoxicity, which can have a diverse clinical presentation ranging from delirium and aphasia to global encephalopathy and seizures [11]. Although the root cause of these toxicities is uncertain, several studies have suggested that they may arise from semi-random mutagenesis when using a retroviral vector during the transduction phase of CAR T cell manufacturing, as viruses have the potential of integrating randomly within the genome including near oncogenic sites $[14,15]$. Although CAR T cell viral vector-mediated oncogenicity has not been directly observed, it is still a concern of the FDA, which recommends follow-up for up to 15 years to monitor adverse effects $[16,17]$. To rectify this, scientists from MSKCC used a gene targeting platform of CRISPR/CAS9, in lieu of viruses, to directly target the T-cell receptor $\alpha$ constant (TRAC) locus during the transduction phase of CAR $\mathrm{T}$ cell development minimizing off-target effects. This approach resulted in more uniform CAR expression with enhanced $\mathrm{T}$ cell potency in an ALL mouse model with minimal side effects [18]. These positive results suggest that modifications in CAR T cell manufacturing can have a profound impact and yield more effective CARs with reduced side effects.

\section{CAR products on the market}

The potential of CAR T cells therapy was realized in August 2017 when Novartis's second-generation CD19targeted CAR $\mathrm{T}$ product containing a 4-1BB-derived costimulatory domain, Kymriah, became the first treatment to receive FDA approval for pediatric $\mathrm{r} / \mathrm{r}$ B-cell ALL. Several months later, Gilead's Yescarta (formerly known as Kite Pharma) received FDA approval for the treatment of Diffuse Large B cell lymphoma [19]. Yescarata, although a CD19-targeted CAR just like Kymriah, contains a CD28 co-stimulatory domain [20]. Celgene's Liso-cel (formerly known as Juno Therapeutics), indicated for Diffuse Large B cell, Non-Hodgkin's, follicular, mantle cell, and primary mediastinal B cell lymphomas, will be submitted for FDA approval before the end of 2018 [19]. Although it is structurally similar to the product from Novartis's with a 4-1BB costimulatory domain, the product utilizes a different manufacturing cell composition consisting of both CD4 and CD8 T cells compared to the others which only use CD4. Over a 6-month period, Liso-cel, in a cohort of 67 patients, demonstrated a $50 \%$ complete remission where only $1 \%$ of patients developed severe CRS and 15\% experienced severe neurotoxicity, while Yescarta showed a 36\% complete remission in 101 patients where 13\% developed CRS and 31\% experienced severe neurotoxicity [21]. In a cohort of 81 patients, Kymriah showed a 30\% complete response with only $23 \%$ experiencing CRS and $12 \%$ severe neurotoxicity [21].

Despite their efficacy, the cost of therapy will become a major concern with Kymriah costing \$475,000 per infusion, while Yescarta will be priced at $\$ 373,000$ [22]. However, manufacturers have a adopted a model of value-based pricing where patients only pay if they respond by the first month post-infusion [22]. In the United States, the Centers for Medicare \& Medicaid Services will compensate Novartis $\$ 500,839$ and Gilead $\$ 395,380$, respectively, for their therapies administered in the out-patient setting and have set a maximum patient out-of-pocket expense of $\$ 1340$ as of 2018 [23]. Although most insurances cover this therapy, manufacturers have devised grants to help those unable to afford treatment. Irrespective, future accessibility of this therapy will largely hinge on affordability as this will determine the number of centers that can offer this treatment to their patients.

\section{CAR T cell resistance and application to solid tumors}

Although CAR $\mathrm{T}$ cells have transformed the treatment of patients with $\mathrm{r} / \mathrm{r}$ B-ALL, several patients have experienced relapse post-therapy [24]. Although the sample is small, studies from patients have shown antigen escape, where relapsed patients with the same malignancy lack express of CD19 rendering CAR targeting ineffective [25]. A potential solution could be to target multiple antigens on cancer cells through engineering either multi-antigen CAR $T$ cells or utilizing multiple CARs each targeting a different antigen [26]. However such an approach may be limited by additional costs of CAR $\mathrm{T}$ cell development. Certain hematological malignancies, such as lymphomas, have demonstrated an increased expression of inhibitory ligands, such as SHP-1 PD-1, CTLA-4, TIM3, LAG-3 and A2AR [27]. To combat this, scientists have proposed combining CAR T cells with checkpoint inhibitors, which have demonstrated improved efficacy in mice [27]. Early clinical trials from B-ALL pediatric patients treated with pembrolizumab (humanized anti-PD-1 antibody) and CD-19-specific CAR T cells showed improved clinical responses and prolonged CAR T cell persistence [28]. Additionally, a recent study has noted the presence of transduction-induced CAR $T$ cell resistance in a relapsed B-ALL patient post therapy, where leukemic cells were found to be transduced with the CAR protein in addition to the $\mathrm{T}$ cell [29]. This allowed the leukemic 
cell to evade initial CAR therapy and ultimately promote disease relapse. Thus, this illustrates the importance of clean CAR $\mathrm{T}$ cell manufacturing to minimize unwanted therapeutic complications.

Despite instances of CAR resistance in hematological malignancies, CAR efficacy in solid tumors has been severely limited. Studies have attributed this to a heterogenous tumor microenvironment that minimizes the number of specific cell surface tumor antigens along with a microenvironment that limits CAR trafficking due to chemokine receptor mismatch, expression of immunosuppressive agents like prostaglandin E2 and cyclooxygenase 2 , and presents an unfavorable metabolic environment that severely limits CAR efficacy [30]. Just like their $r / r$ hematological counterparts, solid tumors have also been shown to exhibit antigenic escape [30]. To circumvent this, researchers at the University of Pennsylvania have proposed designing CARs targeting the unique molecular signatures of cancer cells exhibited in their $O$-linked glycosylation sites, while researchers at MSKCC have designed secretable CARs, called "Armored CARs" [31-33]. This new iteration of CAR T cells expresses a co-stimulatory molecule with a secretable IL-12 cytokine that enhances chemotaxis to solid tumors, provides greater immunological persistence, decreases cellular exhaustion, and affords enhanced cytotoxicity with resistance to the inhibitory tumor microenvironment [33]. Recent animal studies against ovarian cancer utilizing MUC-1616-targeted Armored CAR T cells co-expressing PD-1 checkpoint inhibiting antibodies have been shown to possess more efficacious anti-tumor responses, longer CAR persistence, and enhanced $\mathrm{T}$ cell activation contributing to improved mouse longevity [34]. Thus, this indicates that future CAR enhancements can aid in circumventing the resistant tumor microenvironment to attain better disease control and ultimately result in improve patient mortality.

\section{Novel developments and current clinical trials}

To circumvent the challenges and present limitations of CAR T cell monotherapy, scientists have suggested the use of combinational therapies to enhance CAR efficacy. For instance, several recent studies have shown that combining chemotherapy with CAR $\mathrm{T}$ cells can reduce disease burden, improve tumor antigen recognition, and enhance CAR $T$ cell efficacy and persistence [35-38]. Other studies have suggested that radiotherapy can serve to enhance CAR $\mathrm{T}$ cell efficacy by sensitizing tumor cells to cytotoxic lymphocytes, enhance the trafficking and infiltration of $\mathrm{T}$ cells, improve antigen presentation on tumor cells, and promote overall $\mathrm{T}$ cell survival [39-43]. To combat the immunosuppressive microenvironment induced particularly by solid tumors, studies have augmented CAR $\mathrm{T}$ cell therapy with checkpoint inhibitors, such as anti-PD-1 (nivolumab, pidilizumab and pembrolizumab), anti-PD-L1 (MDX-1105), and anti-CTLA-4 (ipilimumab), and have demonstrated improved tumor regression, increased long-term survival in mice and have improved CAR efficacy and persistence in clinical trials $[44,45]$. It is hoped that these approaches will serve to enhance the effectiveness of CAR T cell therapy and promote a more potent anti-cancer response. Nonetheless, this technology has already demonstrated its merit through its ability to induce complete remission in certain late stage cancers. As this technology continued to be refined, its prevalence will only continue to grow as evident by the increasing number of CAR T cell clinical trials. For instance, over 200 clinical trials against malignancies such as glioblastomas, neuroblastomas, prostate, pancreatic, lung, liver and breast cancers have opened up within the past year worldwide [46]. Although time will tell whether CAR T cell therapy will 1 day circumvent standard therapies of care for certain oncological malignancies, medicine has a new weapon of precision in the longstanding battle with cancer.

\section{Abbreviations \\ ALL: acute lymphoblastic leukemia; CAR: chimeric antigen receptor; CRS: cytokine release syndrome; MSKCC: Memorial Sloan Kettering Cancer Center; r/r: relapsed/refractory; TRAC: T-cell receptor a constant; USFDA: United States Food and Drug Administration.}

\section{Authors' contributions}

YL was responsible for reviewing the literature, summarizing and analyzing the data, and writing the manuscript. The author read and approved the final manuscript.

\section{Acknowledgements \\ Not applicable.}

Competing interests

The authors declare that they have no competing interests.

Availability of data and materials

Data sharing not applicable to this article as no datasets were generated or analyzed during this study.

Consent for publication

This is not applicable for this review.

Ethics approval and consent to participate Not applicable.

Funding

Funding information is not applicable.

\section{Publisher's Note}

Springer Nature remains neutral with regard to jurisdictional claims in published maps and institutional affiliations. 
Received: 23 June 2018 Accepted: 9 November 2018

Published online: 14 November 2018

\section{References}

1. Goldberg C. 2017. The biggest cancer news of 2017? 'CAR-T cells, hands down'. Common Health. http://www.wbur.org/commonheal th/2017/12/28/2017-cancer-news. Accessed 12 Feb 2018

2. Cancer Facts \& Figures. American Cancer Society; 2009: 1-68. http:// www.cancer.org/downloads/STT/2008CAFFfinalsecured.pdf. Accessed 18 June 2018.

3. Chakravarti D, Wong WW. Synthetic biology in cellular immunotherapy. Trends Biotechnol. 2017;33(8):449-61.

4. Stauss HJ. Engineered T cells can fight malignant T cells. Blood. 2015;126(8):927-8.

5. Kuwana Y, Asakura Y, Utsunomiya N, Nakanishi M, Arata Y, et al. Expression of chimeric receptor composed of immunoglobulin-derived $V$ regions and T-cell receptor-derived C regions. Biochem Biophys Res Commun. 1987:149:960-8.

6. Eshhar Z, Waks T, Gross G, Schindler DG. Specific activation and targeting of cytotoxic lymphocytes through chimeric single chains consisting of antibody-binding domains and the gamma or zeta subunits of the immunoglobulin and T-cell receptors. Proc Natl Acad Sci USA 1993;90:720-4

7. Maus MV, June $\mathrm{CH}$. Making better chimeric antigen receptors for adoptive T-cell therapy. Clin Cancer Res. 2016;22(8):1875-84.

8. Levine BL, Miskin J, Wonnacott K, Keir C. Methods and clinical development. Mol Ther. 2017:4:92-101.

9. Rosenberg SA. A unique drug for each patient: a paradigm shift in cancer therapy. The Cancer Letter; 2018.

10. Brentjens RJ, Rivière I, Park JH, Davila ML, Wang X, Stefanski J, Taylor C, Yeh R, Bartido S, Borquez-Ojeda O, Olszewska M, Bernal Y, Pegram H, Przybylowski M, Hollyman D, Usachenko Y, Pirraglia D, Hosey J, Santos E, Halton E, Maslak P, Scheinberg D, Jurcic J, Heaney M, Heller G, Frattini M, Sadelain M. Safety and persistence of adoptively transferred autologous CD19-targeted T cells in patients with relapsed or chemotherapy refractory B-cell leukemias. Blood. 2011;118(18):4817-28.

11. Brentjens RJ, Davila ML, Riviere I, Park J, Wang X, Cowell LG, Bartido S, Stefanski J, Taylor C, Olszewska M, Borquez-Ojeda O, Qu J, Wasielewska T, He Q, Bernal Y, Rijo IV, Hedvat C, Kobos R, Curran K, Steinherz P, Jurcic J Rosenblat T, Maslak P, Frattini M, Sadelain M. CD19-targeted T cells rapidly induce molecular remissions in adults with chemotherapy-refractory acute lymphoblastic leukemia. Sci Transl Med. 2013;5(177):177ra38.

12. Porter DL, Grupp SA, Kalos M, Loren AW, Lledo L, Gilmore J, Milone MC, Chew $\mathrm{A}$, Levine $\mathrm{BL}$, and June $\mathrm{CH}$. Chimeric antigen receptor T cells directed against CD19 induce durable responses and transient cytokine release syndrome in relapsed, refractory CLL and ALL. Proc ASH. Abstract 717; 2012.

13. Giavridis T, van der Stegen SJC, Eyquem J, Hamieh M, Piersigilli A, Sadelain M. CAR T cell-induced cytokine release syndrome is mediated by macrophages and abated by IL-1 blockade. Nat Med. 2018;24:731-8.

14. Jin C, Fotaki G, Ramachandran M, Nilsson B, Essand M, Yu D. Safe engineering of CAR T cells for adoptive cell therapy of cancer using long-term episomal gene transfer. EMBO Mol Med. 2016;8(7):702-11.

15. Vannucci L, Lai M, Chiuppesi F, Ceccherini-Nelli L, Pistello M. Viral vectors: a look back and ahead on gene transfer technology. New Microbiol. 2013;36(1):1-22

16. Scholler J, Brady TL, Binder-Scholl G, Hwang WT, Plesa G, Hege KM, Vogel AN, Kalos M, Riley JL, Deeks SG, Mitsuyasu RT, Bernstein WB, Aronson $\mathrm{NE}$, Levine BL, Bushman FD, June $\mathrm{CH}$. Decade-long safety and function of retroviral-modified chimeric antigen receptor T cells. Sci Transl Med. 2012;4(132):132ra53.

17. Briefing document-testing for replication competent retrovirus (RCR)/ lentivirus $(\mathrm{RCL})$ in retroviral and lentiviral vector based gene therapy products—revisiting current fda recommendations; 2010. https://pdfs. semanticscholar.org/58ac/50e9d532487ea72108af1b1516dc8b3f910 1.pdf. Accessed 18 June 2018.

18. Eyquem J, et al. Targeting a CAR to the TRAC locus with CRISPR/Cas9 enhances tumour rejection. Nature. 2017:543(7643):113-7.
19. Sagonowsky E. Juno Therapeutics CEO Bishop set for $\$ 200 M+$ payday with Celgene buyout. Fierce Pharma; 2018. https://www.fiercephar $\mathrm{ma}$.com/m-a/following-celgene-buyout-juno-therapeutics-ceo-bisho p-set-for-big-m-a-payday. Accessed 12 Feb 2018.

20. Salmikangas P, Kinsella N, Chamberlain P. Chimeric antigen receptor T-cells (CART-Cells) for cancer immunotherapy - moving target for industry? Pharm Res. 2018;35(8):152.

21. "Did ASH Just Change The Juno Best In Class Thesis?" Seeking Alpha; 2017. https://seekingalpha.com/article/4131946-ash-just-change-junobest-class-thesis. Accessed 12 Feb 2018.

22. London S. Logistics of CAR T-Cell Therapy in Real-World Practice. The ASCO Post; 2018. http://www.ascopost.com/issues/may-25-2018/logis tics-of-car-t-cell-therapy-in-real-world-practice/. Accessed 18 June 2018.

23. Gallegos A. Medicare sets outpatient CAR T-cell therapy rates. Hematology News; 2018. https://www.mdedge.com/hematologynews/artic le/164403/business-medicine/medicare-sets-outpatient-car-t-cell-thera py-rates. Accessed 18 June 2018.

24. Ruella M, Maus MV. Catch me if you can: leukemia escape after CD19-directed T cell immunotherapies. Comput Struct Biotechnol J. 2016:14:357-62.

25. Majzner RG, Heitzeneder S, Mackall CL. Harnessing the immunotherapy revolution for the treatment of childhood cancers. Cancer Cell. 2017;31:476-85.

26. Hegde M, Mukherjee M, Grada Z, Pignata A, Landi D, Navai SA, Wakefield A, Fousek K, Bielamowicz K, Chow KK, Brawley VS, Byrd TT, Krebs S, Gottschalk S, Wels WS, Baker ML, Dotti G, Mamonkin M, Brenner MK, Orange JS, Ahmed N. Tandem CAR T cells targeting HER2 and IL13Ralpha2 mitigate tumor antigen escape. J Clin Invest. 2016;126:3036-52.

27. John LB, Devaud C, Duong CP, Yong CS, Beavis PA, Haynes NM, Chow MT, Smyth MJ, Kershaw MH, Darcy PK. Anti-PD-1 antibody therapy potently enhances the eradication of established tumors by gene-modified $T$ cells. Clin Cancer Res. 2013;19:5636-46.

28. Maude SL, Hucks GE, Seif AE, Talekar MK, Teachey DT, Baniewicz D, Callahan C, Gonzalez V, Nazimuddin F, Gupta M, Frey NV, Porter DL, Levine BL, Melenhorst JJ, Lacey SF, June CH, Grupp SA. The effect of pembrolizumab in combination with CD19-targeted chimeric antigen receptor (CAR) T cells in relapsed acute lymphoblastic leukemia (ALL). J Clin Oncol. 2017;35:103.

29. Ruela M, Xu J, Barrett DM, Fraietta JA, Reich TJ, Ambrose DE, Klichinsky M, Shestova O, Patel PR, Kulikovskaya I, Nazimuddin F, Bhoj VG, Orlando EJ, Fry TJ, Bitter H, Maude SL, Levine BL, Nobles CL, Bushman FD, Young RM, Scholler J, Gill SI, June CH, Grupp SA, Lacey SF, Melenhorst J. Induction of resistance to chimeric antigen receptor $T$ cell therapy by transduction of a single leukemic B cell. Nat Med. 2018;24:1499-503.

30. Newick K, Moon E, Albelda SM. Chimeric antigen receptor T-cell therapy for solid tumors. Mol Ther Oncolytics. 2016;3:16006.

31. Steentoft C, Migliorini D, King TR, Mandel U, June CH, Posey Avery D. Glycan-directed car-T cells. Glycobiology. 2018. https://doi.org/10.1093/ glycob/cwy008.

32. Ho W-L, Hsu W-M, Huang M-C, Kadomatsu K, Nakagawara A. Protein glycosylation in cancers and its potential therapeutic applications in neuroblastoma. J Hematol Oncol. 2016;9:100

33. Yeku OO, Purdon TJ, Koneru M, Spriggs D, Brentjens RJ. Armored CART cells enhance antitumor efficacy and overcome the tumor microenvironment. Sci Rep. 2017;7:10541.

34. Rafiq S, Yeku OO, Jackson HJ, Purdon TJ, van Leeuwen DG, Drakes DJ, Song M, Miele MM, Li Z, Wang P, Yan S, Xiang J, Ma X, Seshan VE, Hendrickson RC, Liu C, Brentjens RJ. Targeted delivery of a PD-1-blocking sCFv by CAR-T cells enhances anti-tumor efficacy in vivo. Nat Biotechnol. 2018;36(9):847-56.

35. Alizadeh D, Trad M, Hanke NT, Larmonier CB, Janikashvili N, Bonnotte $B$, Katsanis E, Larmonier N. Doxorubicin eliminates myeloid-derived suppressor cells and enhances the efficacy of adoptive T-cell transfer in breast cancer. Cancer Res. 2014;74:104-18.

36. Proietti E, Greco G, Garrone B, Baccarini S, Mauri C, Venditti M, Carlei D, Belardelli F. Importance of cyclophosphamide-induced bystander effect on T cells for a successful tumor eradication in response to adoptive immunotherapy in mice. J Clin Invest. 1998;101:429-41.

37. Muranski P, Boni A, Wrzesinski C, Citrin DE, Rosenberg SA, Childs R, Restifo NP. Increased intensity lymphodepletion and adoptive immunotherapyhow far can we go? Nat Clin Pract Oncol. 2006;3:668-81. 
38. Rosenberg SA, Dudley ME. Adoptive cell therapy for the treatment of patients with metastatic melanoma. Curr Opin Immunol. 2009;21:233-40.

39. Higgins JP, Bernstein MB, Hodge JW. Enhancing immune responses to tumor-associated antigens. Cancer Biol Ther. 2009;8:1440-9.

40. Matsumura S, Wang B, Kawashima N, Braunstein S, Badura M, Cameron TO, Babb JS, Schneider RJ, Formenti SC, Dustin ML, Demaria S. Radiationinduced CXCL16 release by breast cancer cells attracts effector T cells. J Immunol. 2008;181:3099-107.

41. Lugade AA, Sorensen EW, Gerber SA, Moran JP, Frelinger JG, Lord EM. Radiation-induced IFN-gamma production within the tumor microenvironment influences antitumor immunity. J Immunol. 2008;180:3132-9.

42. Deng L, Liang H, Xu M, Yang X, Burnette B, Arina A, Li XD, Mauceri H, Beckett M, Darga T, Huang X, Gajewski TF, Chen ZJ, Fu YX, Weichselbaum RR. STING-Dependent Cytosolic DNA sensing promotes radiation-induced type I interferon-dependent antitumor immunity in immunogenic tumors. Immunity. 2014:41:843-52.
43. Weiss T, Weller M, Guckenberger M, Sentman CL, Roth P. NKG2D-based CART cells and radiotherapy exert synergistic efficacy in glioblastoma. Cancer Res. 2018;78:1031-43.

44. Liu X, Ranganathan R, Jiang S, Fang C, Sun J, Kim S, Newick K, Lo A, June $\mathrm{CH}$, Zhao Y, Moon EK. A chimeric switch-receptor targeting PD1 augments the efficacy of second-generation CART cells in advanced solid tumors. Cancer Res. 2016;76:1578-90.

45. Gargett T, Yu W, Dotti G, Yvon ES, Christo SN, Hayball JD, Lewis ID, Brenner MK, Brown MP. GD2-specific CAR T cells undergo potent activation and deletion following antigen encounter but can be protected from activation-induced cell death by PD-1 blockade. Mol Ther. 2016;24:1135-49.

46. Yu S, Li A, Liu Q, Li T, Yuan X, Han X, Wu K. Chimeric antigen receptor T cells: a novel therapy for solid tumors. J Hematol Oncol. 2017;10(1):78.
Ready to submit your research? Choose BMC and benefit from:

- fast, convenient online submission

- thorough peer review by experienced researchers in your field

- rapid publication on acceptance

- support for research data, including large and complex data types

- gold Open Access which fosters wider collaboration and increased citations

- maximum visibility for your research: over $100 \mathrm{M}$ website views per year

At BMC, research is always in progress.

Learn more biomedcentral.com/submissions 